\title{
Differential effects of Fas cross-linking on phospholipase D activation and related lipid metabolism in Fas-resistant A20 cells
}

\author{
Si Young Lim ${ }^{1,2}$, Sung-Chang Lee ${ }^{1}$, \\ Incheol Shin ${ }^{1}$, Joong-Soo Han ${ }^{1,3,4}$ \\ ${ }^{1}$ Institute of Biomedical Science and Department of Biochemistry, \\ College of Medicine, Hanyang University, Seoul 133-791, Korea \\ ${ }^{2}$ Department of Internal Medicine, Kangbuk Samsung Hospital, Col- \\ lege of Medicine, Sungkyunkwan University, Seoul 888-666, Korea \\ ${ }^{3}$ Research Center for Bio-Medicinal Resources, Pai Chai University, \\ Taejon 302-735, Korea \\ ${ }^{4}$ Corresponding author:Tel, +81-2-2290-0623; \\ Fax, +82-2-2294-6270; E-mail, jshan@ hanyang.ac.kr
}

Accepted 4 July 2002

Abbreviations: DAG, diacylglycerol; PC, phosphatidylcholine; PCPLC, phosphatidylcholine-specific phospholipase C; PLD, phospholipase D; PMA, phorbol 12-myristate 13-acetate; SMase, sphingomyelinase; PEt, phosphatidylethanol

\begin{abstract}
A20 murine lymphoma cells undergoing Fas-mediated apoptosis showed increase in the activity of phospholipase $D$ (PLD), which is involved in proliferative or mitogenic cellular responses. Using A20 cell lines that were resistant to Fas-induced apoptosis, we investigated the differential effects of Fas cross-linking on PLD activity and sphingolipid metabolism. The basal PLD activities in all of the selected three Fasresistant clones (\#5, \#8, and \#11) were about 2 4 folds higher than that of wild type A20 cells. Among the PLD isoforms, PLD2 expression was increased in all of the selected Fas-resistant clones. The Fas downstream signaling events triggered by Fas cross-linking, including the activations of PLD, phosphatidyIcholine-specific phospholipase C (PC-PLC), sphingomyelinase (SMase), the increase in diacylglycerol (DAG) and protein phosphorylation levels, and the translocation of protein kinase $C$ to membrane were not changed in both of Fas-resistant clone \#5 and \#8. In contrast, Fas cross-linking stimulated the activity of PLD, PC-PLC, and SMase, translocation of PKC, and protein phosphorylation in Fas-resistant clone \#11, similar to that of wild type cells. We also found that clone \#11 had a different Fas sequence encoding Fas $B$ which has been known to inhibit Fas-induced apoptosis. These findings suggest that increased PLD2
\end{abstract}

expression resulting in increased basal PLD activity and the blockade of Fas downstream signaling cascades may be involved to limit apoptosis induced by Fas cross-linking.

Keywords: Fas, phsopholipase D, phospholipase C, sphingomyelinase, protein kinase $\mathrm{C}$, apoptosis

\section{Introduction}

The Fas antigen is cell surface protein that mediates apoptosis (Heller and Krönke, 1994; Nagata and Goldstein, 1995). The Fas antigen consists of 319 amino acids (human) or 306 amino acids (mouse) and has similarity to the tumor necrosis factor receptors and lowaffinity nerve growth factor (Itoh et al., 1991; WatanabeFukunaga et al., 1992). Activation of Fas by its ligand or by cross-linking with anti-Fas antibodies induces apoptosis (Itoh et al., 1991; Goillot et al., 1997). Apoptosis induced by Fas activation has been shown to be involved in the regulation of lymphocyte death in the peripheral immune system (Dhein et al., 1995) and T cell-mediated cytotoxicity (Kagi et al., 1994). However, engagement of Fas may also result in the generation of nonapoptotic signals. Fas has been reported to generate costimulatory signals in lymphocytes (Alderson et al., 1993).

The early biochemical events involved in Fas signaling are still unknown in many aspects. A recent report has suggested that multiple phospholipid hydrolysis by phosphatidylcholine-specific phospholipase C (PC-PLC) and sphingomyelinase (SMase) contributes in Fas signaling. The sequential activation of PC-PLC, acidic SMase, and subsequent rise in ceramide level were presumed to be responsible for Fas-generated apoptotic signal in lymphoid cells (Cifone et al., 1995). We have also reported the involvement of PC-PLC activity in Fas-mediated phospholipase D (PLD) activation in A20 cells and further showed that diacylglycerol (DAG) produced by Fasinduced activation of PC-PLC is responsible for subsequent activation of protein kinase $\mathrm{C}$ (PKC) and PLD (Han et al., 1999). In addition, cell lines devoid of functional PC-PLC activity could exhibit enhanced PLD activity by exogenous addition of Bacillus cereus PCPLC (Shin and Han, 2000).

Tumor necrosis factor receptor 1 (TNFR1) and Fas are known to induce an elevation of intracellular ceramide content. Ceramide is a product of sphingomyelin breakdown by SMase, and is thought to 
play a role as a crucial mediator of apoptosis (Hannun and Obeid, 1995). Ceramide acts as a lipid second messenger to mediate the effects of extracellular agents on cell differentiation, growth inhibition, and apoptosis. Two types of SMases, acidic and neutral SMase, are known to be responsible for ceramide generation by Fas cross-linking. There are some conflicting reports that PLD, a major enzyme involved in phosphatidylcholine hydrolysis, is affected by ceramide signaling. In FRTL-5 cells, C2-ceramide treatment induced apoptosis and decreased PLD mRNA expression, suggesting that ceramide can inhibit the PLD activity in an early apoptotic phase and down-regulation of the levels of PLD mRNA may be implicated in apoptotic process (Park et al., 1999). Both C2- and C6-ceramides inhibit the increase in PLD activity by phosphatidate, lysophosphatidate, phorbol ester, or serum in rat fibroblast (Gomez-Munoz et al., 1994), while C6ceramide and $S$. aureus SMase are able to activate PLD in human fibroblast (Meacci et al., 1996). Recently, our laboratory found that ceramide could not inhibit PLD activity or participate in the Fas cross-linking-induced signaling that ultimately cumulates in the PKCdependent activation of PLD in murine lymphoma cells (Han and Shin, 2000)

The susceptibility of cells to apoptosis induced by Fas cross-linking is regulated not only through the density of Fas on the cell surface, but also by other mechanisms through FLIP (FLICE-inhibitory protein) (Djerbi et al., 1999) or soluble isoform of Fas (FasB) (Hughes and Nicholas, 1995). FLIP interact with adaptor protein FADD and protease FLICE, and potently inhibit apoptosis induced by all known human death receptor (Irmler et al., 1997). Fas B also acts physiologically to limit apoptosis induced by Fas cross-linking because this soluble isoform of Fas retains ligand-binding activity and competes for ligand, thus inhibiting receptor function (Hughes and Nicholas, 1995).

In the present study, we investigated to delineate the differential effects of Fas cross-linking on PLD activation and sphingolipid metabolism between wild type A20 and three different A20 cells resistant to Fas-induced apoptosis (Fas-resistant A20 cells) which were cloned in our laboratories unexpectedly.

\section{Materials and Methods}

\section{Materials}

Anti-Fas monoclonal antibody (Jo2) was obtained from Pharmingen (San Diego, CA, USA). Anti-PLD antibody employed in the present study was produced as previously described (Lee et al., 2000). [ $\left.{ }^{3} \mathrm{H}\right]$ palmitic acid was purchased from New England Nuclear (Boston, MA, USA). Phosphatidylethanol (PEt) was from Avanti polar
Lipid, Inc. (Alabaster, AL, USA). Fetal bovine serum (FBS), penicillin/streptomycin solution and RPMI 1640 medium were from Gibco-BRL (Gaithersburg, MD, USA). Polyclonal anti-protein kinase $C \beta$ antibody was obtained from Santa Cruz Biotechnology (Santa Cruz, CA, USA). Anti-FLIP antibody was obtained from Upstate Biotechnology (Lake Placid, NY, USA).

\section{Cell culture}

A20 murine B lymphoma cell line obtained from American Type Culture Collection (ATCC TIB208) were cultured at $37^{\circ} \mathrm{C}$ in RPMI-1640 medium supplemented with $10 \%$ FBS, 100 units $/ \mathrm{ml}$ penicillin and $100 \mu \mathrm{g} / \mathrm{ml}$ streptomycin.

\section{Generation of Fas resistant $\mathrm{A} 20$ cell clones}

A20 cells rapidly growing in $100 \mathrm{~mm}$ dish $\left(1 \times 10^{6}\right.$ cells/ $\mathrm{ml}$ ) were treated with $200 \mathrm{ng} / \mathrm{ml}$ of anti-Fas monoclonal antibody. After $24 \mathrm{~h}$, the floating cells (dead cells) were removed by aspiration and selection with anti-Fas monoclonal antibody was continued for additional $48 \mathrm{~h}$. After total $72 \mathrm{~h}$ of selection, the medium containing antiFas monoclonal antibody was discarded and very small portion of surviving cells were resuspended in medium containing anti-Fas monoclonal antibody and cell density was adjusted to 1 cells/200 $\mu$ l. And the surviving A20 cells were seeded on 96-well plate. After seeding, each well was carefully observed under inverted microscope and wells containing more than 1 cell were excluded. The surviving clones were grown in the presence of anti-Fas monoclonal antibody for 2 weeks and clones showing rapid growth rate were selected and transferred onto 24-well plates. After 1 week, the clones were transferred onto 6-well plates and we got three Fas-resistant clones, which were designated as FasR \#5, FasR \#8, and FasR \#11 clones, respectively. All these clones showed normal growth pattern in the presence of anti-Fas monoclonal antibody. The resistant clones were then transferred to $100 \mathrm{~mm}$ dish and maintained in normal medium. There was no reverse generation of Fas-sensitive phenotype in the absence of anti-Fas monoclonal antibody.

\section{Reverse transcription (RT) PCR, cloning and sequencing}

Fas cDNAs were prepared from total mRNA extracted from wild type A20 cells and Fas-resistant clones, respectively, using MMLV reverse transcriptase and Fas specific primer (5'-CAATGAAGTATCAACTTACCAT-3'). Murine Fas message was amplified by PCR from Fas cDNA using forward primer (5'-GCTGACGACATGCTG TGGCAT-3') and reverse primer (5'-GTAGTTTTCAC TCC AGACAT-3'). After PCR, PCR product was cloned into pGEM-T easy vector system (Promega), and sequenced by ABI Prism Big-Dye method (Perkin Elmer) using T7 primer and Sp6 primer. 


\section{Determination of PLD activity and measurement of DAG}

PLD activity was determined as previously described by measuring $\left[{ }^{3} \mathrm{H}\right] \mathrm{PEt}$ produced via PLD catalyzed transphosphatidylation in $\left[{ }^{3} \mathrm{H}\right]$ palmitic acid labeled cells (Shin and Han, 2000). Briefly, A20 cells $\left(1.5 \times 10^{6}\right.$ cells/ well) cultured on six-well plates were metabolically labeled with $1 \mu \mathrm{Ci} / \mathrm{ml}$ of $\left[{ }^{3} \mathrm{H}\right]$ palmitic acid in serum free medium for $18 \mathrm{~h}$. The cells were then pretreated with $1 \%(\mathrm{v} / \mathrm{v})$ ethanol for $15 \mathrm{~min}$ before stimulation with antiFas monoclonal antibody. After the stimulation, the cells were quickly washed with ice-cold phosphate buffered saline and suspended in $0.5 \mathrm{ml}$ of ice-cold methanol. Lipids were extracted according to the method of Bligh and Dyer (1959). PEt was separated from other phospholipids by a thin layer chromatography (TLC) on silica gel $60 \mathrm{~A}$ plates with a solvent system of ethyl acetate/isooctane/acetic acid/water (110:50:20:100, v/v) and DAG was separated with a solvent system of toluene/ ether/ethanol/con centrated $\mathrm{NH}_{4} \mathrm{OH}$ (50:30:20:0.2, v/v). The regions corresponding to the authentic $\mathrm{PEt}$ bands and the DAG bands were identified with $0.002 \%(\mathrm{w} / \mathrm{v})$ primulin in $80 \%(\mathrm{v} / \mathrm{v})$ acetone, scraped and counted using a scintillation counter, respectively.

\section{Western analysis}

For the Western blot analysis of PLD, the cells were lysed with radioimmune precipitation assay buffer (20 $\mathrm{mM}$ Hepes, $\mathrm{pH} 7.2,1 \%$ Triton $\mathrm{X}-100,1 \%$ sodium deoxycholate, $0.2 \% \mathrm{SDS}, 150 \mathrm{mM} \mathrm{NaCl}, 1 \mathrm{mM} \mathrm{Na}_{3} \mathrm{VO}_{4}$, $1 \mathrm{mM} \mathrm{NaF}, 10 \%$ glycerol, $10 \mu \mathrm{g} / \mathrm{ml}$ leupeptin, $10 \mu \mathrm{g} / \mathrm{ml}$ aprotinin, $1 \mathrm{mM}$ phenymethylsulfonyl fluoride). Protein concentrations were determined using the Bio-Rad Protein Assay with bovine serum albumin as a standard. Equal protein aliquots of cell lysates $(40 \mu \mathrm{g})$ were subjected to SDS-PAGE and Western blot analysis using the indicated antibody. To analysis the expression level of FLIP, cells were resuspended in $1 \mathrm{ml}$ lysis buffer (50 mM NaCl, $1 \mathrm{mM} \mathrm{MgCl}_{2}, 2 \mathrm{mM}$ EDTA, $1 \mathrm{mM}$ dithiothreitol, $1 \mathrm{mM}$ phenylmethylsulfonyl fluoride, $10 \mu \mathrm{g} /$ $\mathrm{ml}$ aprotinin, $10 \mu \mathrm{g} / \mathrm{ml}$ leupeptin, $50 \mathrm{mM}$ Hepes, $\mathrm{pH}$ 7.5) and disrupted by sonication. The lysates were loaded onto $15 \%$ SDS-PAGE and the proteins were transferred onto nylon membranes using a Bio-Rad Mini Trans-Blot Electrophoretic Transfer Cell. The membranes blocked for $1 \mathrm{~h}$ with TTBS (Tris-buffered saline containing $0.01 \%$ Tween 20) with $5 \%(\mathrm{w} / \mathrm{v})$ non-fat dry skim milk and incubated for an additional $1 \mathrm{~h}$ with diluted specific antiFLIP antisera $(1 \mu \mathrm{g} / \mathrm{ml})$. The membrane was washed two times for 10 min with water before being incubated with horseradish peroxidase conjugated anti-rabbit IgG for $1 \mathrm{~h}$. Visualization of the immune complexes was performed with horseradish peroxidase-dependent enhanced chemiluminescence (Amersham, Buckinghamshire, UK).

\section{Measurement of water-soluble products of PC hydrolysis}

The analysis of water-soluble products of phosphatidylcholine breakdown was performed according to the method of Cook and Wakelam (1989) with some modifications. A20 cells on 6-well plates were metabolically labeled with $1 \mu \mathrm{Ci} / \mathrm{ml}$ of $\left[\right.$ methyl- $\left.{ }^{3} \mathrm{H}\right]$ choline chloride in the serum-free medium for $18 \mathrm{~h}$. Following removal of the labeling medium, the cells were washed with fresh serumfree medium and stimulated with anti-Fas monoclonal antibody. After stimulation, the cells were resuspended in $0.5 \mathrm{ml}$ of ice-cold methanol and allowed to sit on ice $10 \mathrm{~min}$. then suspension was added to $0.35 \mathrm{ml}$ of chloroform and then added to $0.5 \mathrm{ml}$ of water. Water-soluble phosphocholine was analyzed by TLC using a solvent system of methanol/0.5\% NaCl/ammonia(50:50:1, v/v/v) in two runs with intermittent drying (Ha and Exton, 1993). Commercial standards, phosphocholine was cochro-matogramed and visualized in iodine vapor. Spots were scraped off, and radioactivity was determined by liquid scintillation counting.

\section{Translocation of PKC}

Serum-starved cells were incubated with $200 \mathrm{ng} / \mathrm{ml}$ of anti-Fas monoclonal antibody for 30 min or $3 \mathrm{~h}$, scraped in ice-cold phosphate buffered saline and harvested by microcentrifugation. The cells were then resuspended in $1 \mathrm{ml}$ lysis buffer $\left(50 \mathrm{mM} \mathrm{NaCl}, 1 \mathrm{mM} \mathrm{MgCl}_{2}, 2 \mathrm{mM}\right.$ EDTA, $1 \mathrm{mM}$ dithiothreitol, $1 \mathrm{mM}$ pheny-Imethylsulfonyl fluoride, $10 \mu \mathrm{g} / \mathrm{ml}$ aprotinin, $10 \mu \mathrm{g} / \mathrm{ml}$ leupeptin, $50 \mathrm{mM}$ Hepes, $\mathrm{pH}$ 7.5) and disrupted by sonication. The cytosolic fraction was separated from the particulate fraction by centrifugation at $100,000 \mathrm{~g}$ for $1 \mathrm{~h}$. SDSPAGE was performed using $10 \%$, and the proteins were transferred onto nylon membranes. The membranes blocked for $1 \mathrm{~h}$ with TTBS (tris-buffered saline containing $0.01 \%$ Tween 20 ) with $5 \%(w / v)$ non-fat dry skim milk and incubated for an additional $1 \mathrm{~h}$ with diluted specific antiPKC antisera $(1 \mu \mathrm{g} / \mathrm{ml})$. Following the incubation with alkaline phosphatase conjugated-anti-rabbit IgG, the blots were developed using the phosphatase substrate system (Kirkegaard and Perry Laboratories).

\section{MTT(3-(4,5-dimethylthiazol-2-yl)-2,5-diphenyl tetrazolium bromide) assay}

The MTT assays were performed as previously described (Mosmann., 1983). Cells were plated onto 96-well plate $\left(1 \times 10^{5}\right.$ cells $\left./ \mathrm{ml}\right)$ and treated with $200 \mathrm{ng} /$ $\mathrm{ml}$ of anti-Fas monoclonal antibody for predetermined time. MTT solution $(0.4 \mathrm{mg} / \mathrm{ml})$ was added and incubated for 4 hours at $37^{\circ} \mathrm{C}$ and centrifuged at 400 $g$ for $5 \mathrm{~min}$. The resulting supernatant was discarded and $150 \mu \mathrm{l}$ of dimethyl sulfoxide was added. After shaking the plates for $10 \mathrm{~min}$, the optical density was immediately measured at $540 \mathrm{~nm}$. 


\section{Sphingomyelin hydrolysis assay}

Sphingomyelin and its hydrolysis product, ceramide levels were monitored by the method of Santana et al. (1995) with slight modifications. A20 cells were labeled with $2 \mu \mathrm{Ci} / \mathrm{ml}$ of $\left[{ }^{3} \mathrm{H}\right]$ serine in the minimum essential medium for $18 \mathrm{~h}$ and treated with anti-Fas monoclonal antibody for various time periods. Then, the cells were quickly washed with ice-cold phosphate-buffered saline and suspended in ice-cold methanol. After the lipid extraction according to the method of Bligh and Dyer (1959), lipids in the low organic phase were applied to a TLC silica gel plate. The plates were then developed using two sequential developments with ethyl acetate/ isooctane/acetic acid/water (130:20:30:100, v/v) as the first solvent and chloroform/methanol/acetic acid/water $(100: 60: 20: 5, v / v)$ as the second solvent. Fractions that comigrated with the same retention factors as authentic sphingomyelin and ceramide were scraped into scintillation vials and the associated radioactivity was determined by liquid scintillation counting.

\section{Measurement of protein phosphorylation in cells}

A20 cells grown in six-well plates were labeled with $100 \mu \mathrm{Ci} /$ $\mathrm{ml}$ of $\left.{ }^{32} \mathrm{P}\right]$ orthophosphate for $6 \mathrm{~h}$ in the serum-free medium. After stimulation of the cells with anti-Fas monoclonal antibody for $10 \mathrm{~min}$, cells were quickly washed with ice-cold phosphate-buffered saline and then resuspended in $1 \mathrm{ml}$ lysis buffer ( $50 \mathrm{mM} \mathrm{NaCl}, 1 \mathrm{mM} \mathrm{MgCl} 2,2 \mathrm{mM}$ EDTA, $1 \mathrm{mM}$ dithiothreitol, $1 \mathrm{mM}$ phenylmethyl-sulfonyl fluoride, $10 \mu \mathrm{g} /$ $\mathrm{ml}$ aprotinin, $10 \mu \mathrm{g} / \mathrm{ml}$ leupeptin, $50 \mathrm{mM}$ Hepes, $\mathrm{pH}$ 7.5) and disrupted by sonication. The lysates were loaded onto $10 \%$ SDS-PAGE and the cellular phosphoproteins were analyzed by autoradiography.

\section{Results}

\section{Selection of Fas-resistant cell clones and characterization of Fas antigen}

A20 cells undergoing Fas-induced apoptosis showed increase in PLD activity, which is involved in proliferative or mitogenic cellular responses (Han et al., 1999). To determine the roles of PLD in Fas-induced apoptosis, A20 cells resistant to Fas-induced apoptosis were selected and compared the effect of Fas cross-linking on signaling leading to PLD activation in wild type A20 cells and Fas resistant A20 cells. Three Fas-resistant clones, FasR \#5, FasR \#8, and FasR \#11 clones were selected. All of three Fas-resistant clones showed no apoptotic cell death by anti-Fas monoclonal antibody as compared to wild type cells, indicating that these selected clones are indeed Fas-resistant. However, similar to wild type A20 cells, all these three Fasresistant clones showed the expression of the 43kDaFas antigen as revealed by immunoblot with anti-Fas
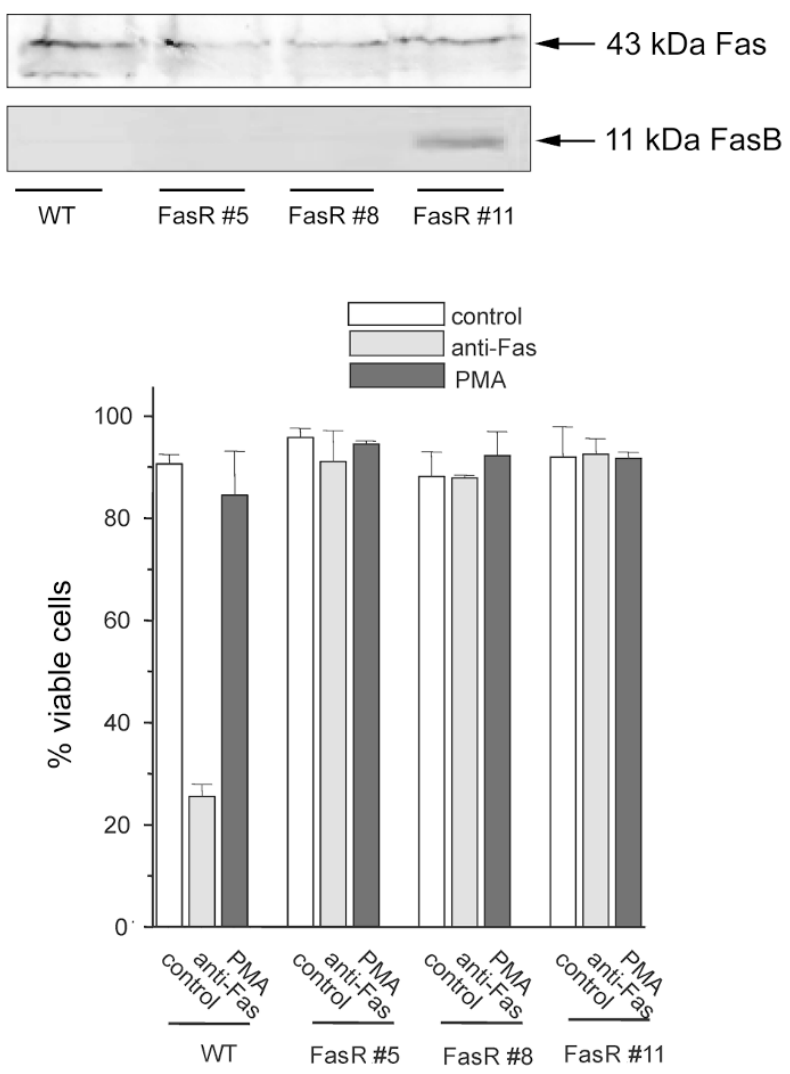

Figure 1. Effect of anti-Fas monoclonal antibody on cell survival of wild type A20 cells and Fas-resistant A20 cell clones. Cells grown on 96-well plate $\left(1 \times 10^{5} \mathrm{cells} / \mathrm{ml}\right)$ were serum-starved for $18 \mathrm{~h}$ and treated with $200 \mathrm{ng} / \mathrm{ml}$ of anti-Fas monoclonal antibody for $3 \mathrm{~h}$ or $200 \mathrm{nM}$ of PMA for $30 \mathrm{~min}$. Cell viability was measured using MTT assay as described in Materials and Methods. Data are means \pm S.D. from triplicate experiments. Upper and lower inserts show immunoblots of Fas surface antigen and soluble FasB probed with anti-Fas monoclonal antibody.

monoclonal antibody, suggesting that these resistant phenotypes were not conferred by absence of Fas expression (Figure 1). Among these Fas-resistant clones, FasR \#11 clone possessed additional $11 \mathrm{kDa}$ FasB. FasB has been known to be a soluble isoform of mouse Fas, which is generated by alternative splicing of Fas mRNA to a newly identified exon located between exons 2 and 3 of the previously published Fas sequence. This soluble isoform of Fas retains ligandbinding activity and competes for ligand, thus inhibiting receptor function (Hughes and Crispe, 1995). To compare the Fas cDNA sequences in Fas-resistant clones with wild type cells, we performed RT-PCR and sequencing. As shown in Figure 2, FasR \#5 and FasR \#8 clones possessed the same wild type Fas antigen sequence. Only FasR \#11 clone showed a different size of Fas antigen. There was a 158-bp insertion between second and third exons of the reported Fas sequence. The incorporation of this 158-bp insertion caused a frame shift in exon 3 of the gene, leading to stop codon 


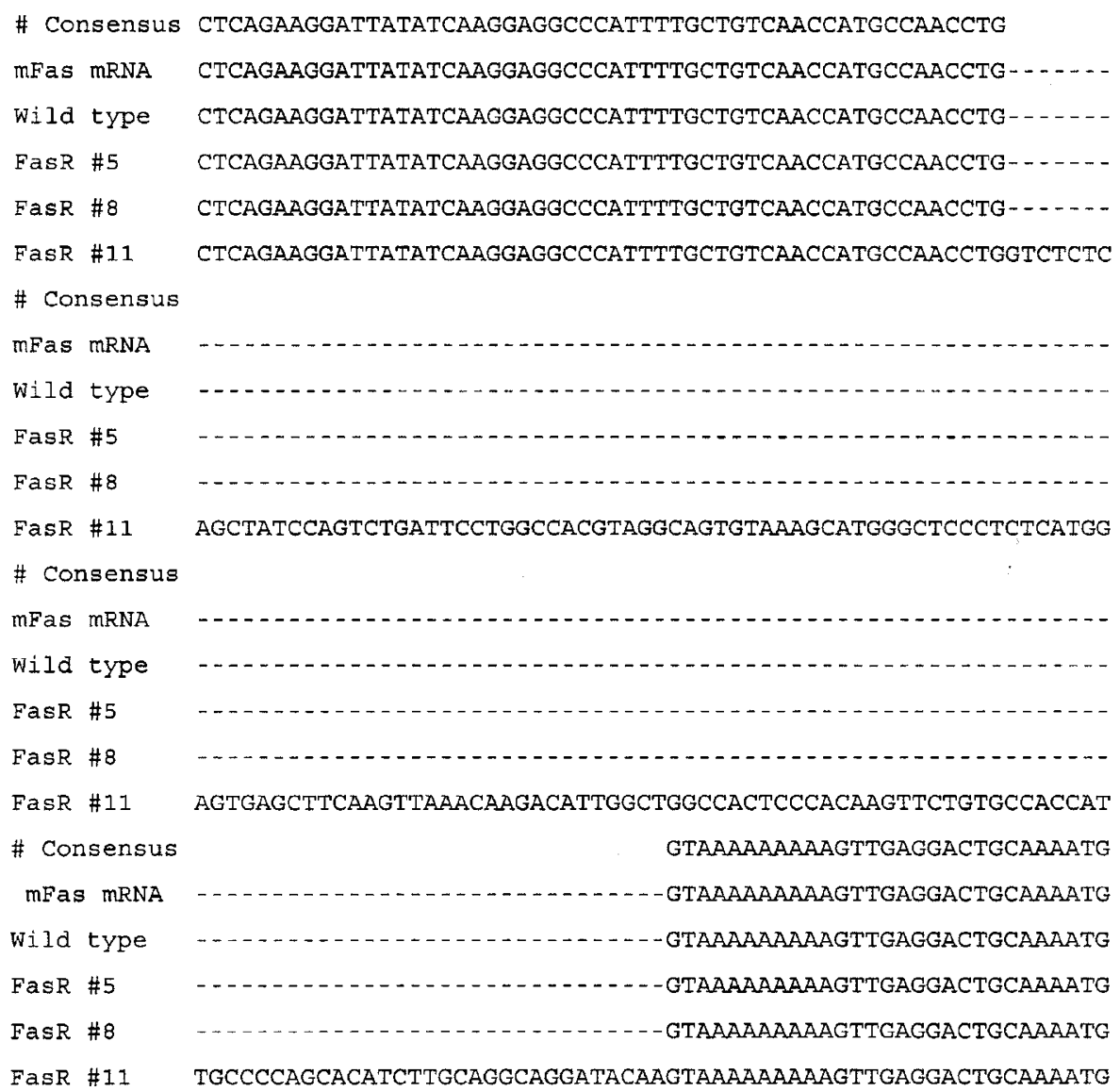

Figure 2. cDNA sequences of Fas antigen in wild type A20 cells and Fas-resistant A20 cell clones. Fas cDNAs were prepared from total mRNA extracted from wild type A20 cells and Fas-resistant clones, respectively using MMLV reverse transcriptase and Fas specific primer. Murine Fas message was amplified by PCR from Fas cDNA. After PCR, the product was cloned and sequenced. The 158-bp nucleotide sequence was inserted between second and third exons of the reported Fas sequence in FasR \#11 clones, leading to a stop codon 27-bp into exon 3. This truncated Fas is called as FasB whose molecular mass is $11 \mathrm{k} \mathrm{Da}$.

27-bp into exon 3. The translated product of this message, Fas B, would be a truncated Fas protein. The predicted molecular mass of FasB is $11 \mathrm{kDa}$.

\section{Effects of anti-Fas monoclonal antibody on PLD activity in wild type A20 cells and Fas-resistant A20 cell clones}

As shown in Figure 3, the Fas-resistant clones generally showed increased basal PLD activities about 2-4 folds higher than wild type A20 cells. In wild type A20 cells, Fas cross-linking brought an approximately 2.5 -fold increase in PLD activity in $3 \mathrm{~h}$ after $200 \mathrm{ng} / \mathrm{ml}$ of antiFas monoclonal antibody treatment (Han et al., 1999). FasR \#5 clone showed no effect of Fas treatment on PLD activity. Furthermore, in case of FasR \#8 clone, Fas cross-linking with anti-Fas monoclonal antibody induced a decrease of PLD activation by $30 \%$ in comparison with the control. Only FasR \#11 clone showed marginal increase in PLD activity by Fas crosslinking. PMA treatment showed a significant increase in
PLD activity in both FasR \#5 and FasR \#11 clones but not in FasR \#8 clone. At present, we do not have any explanation for the decrease in PLD activity by Fas cross-linking in FasR \#8 clone.

\section{Changes of PLD2 expression in Fas-resistant A20 cell clones}

Examination of increased PLD isoforms in A20 cells showed only $100-k D a$ PLD2 was detected by anti-PLD antibody, and not 120-kDa PLD1 (Figure 4). Expression of PLD2 in all of three Fas-resistant clones was increased in comparison with that of wild type A20 cells. Thus, it would appear that overexpression of PLD2 in Fas-resistant $A 20$ cells are mainly responsible for the increased basal PLD activity found in Fas-resistant cells.

Effects of anti-Fas monoclonal antibody on PC-PLC activity and DAG level in wild type A20 cells and Fas-resistant A20 cell clones

Fas cross-linking with anti-Fas mAb treatment increased 


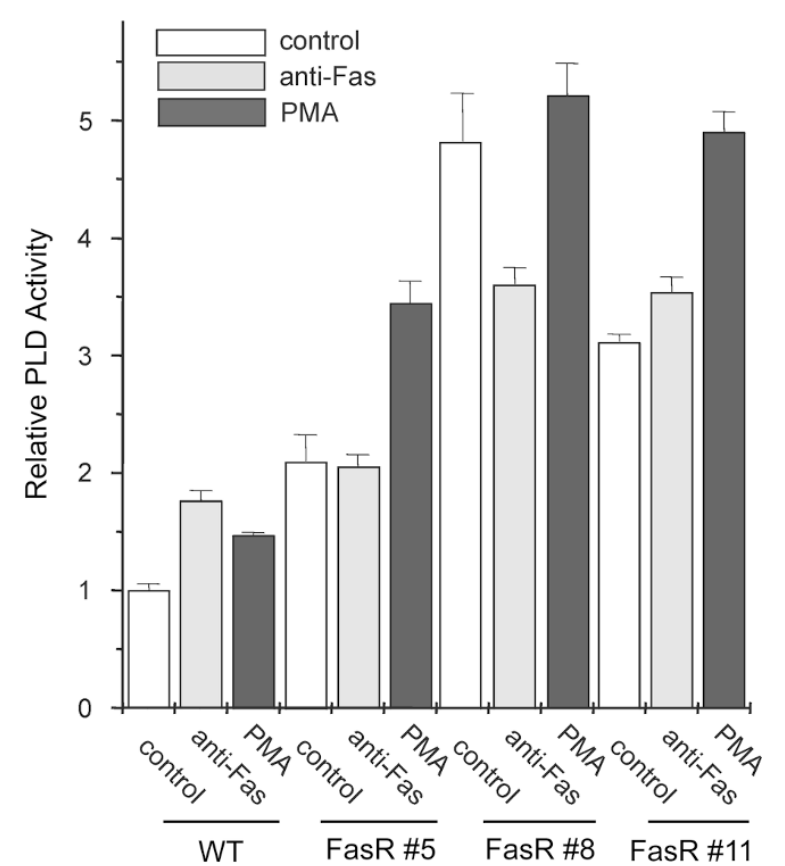

Figure 3. Effects of anti-Fas monoclonal antibody on PLD activity in wild type A20 cells and Fas-resistant A20 cell clones. A20 cells grown on 6-well plates at the density of $1 \times 10^{6} \mathrm{celll} / \mathrm{ml}$ were metabolically labeled with 1 $\mu \mathrm{Ci} / \mathrm{ml}$ of $\left[{ }^{3} \mathrm{H}\right]$ palmitic acid for $18 \mathrm{~h}$ in a serum-free medium, and were stimulated with $200 \mathrm{ng} / \mathrm{ml}$ of anti-Fas monoclonal antibody for $3 \mathrm{~h}$ or $200 \mathrm{nM}$ of PMA for $30 \mathrm{~min}$. Determination of PEt level was performed as described in Materials and Methods. Data are mean \pm S.D. from triplicate experiments.

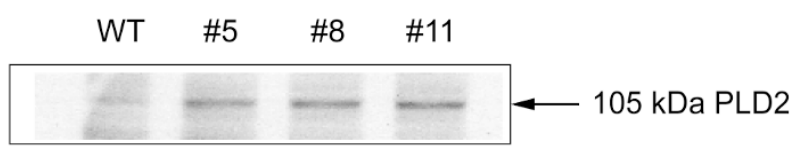

Figure 4. Western analysis of PLD2 in wild type A20 cells and Fas-resistant A20 cell clones. Wild type (WT) A20 cells and Fas-resistant A20 clones (\#5, $\# 8$, and \#11) were lysed with radioimmune precipitation assay buffer. Equal protein aliquots of cell lysates $(40 \mu \mathrm{g})$ were subjected to SDS-PAGE and Western analysis using the anti-PLD antibody.

PC-PLC activity and DAG production in both of wild type A20 cells and FasR \#11 clone. In contrast to FasR \#11, FasR \#5 clone had no effect on the PC-PLC activity and DAG level by Fas cross-linking, and FasR \#8 showed decrease in both PC-PLC activity and DAG level by the treatment of anti-Fas monoclonal antibody (Figure 5). FasR \#8 and FasR \#11 clones showed higher basal PC-PLC activity than wild type A20 cells. But DAG levels of Fas resistant clones were similar to that of wild type A20 cells.

Effects of anti-Fas monoclonal antibody on PKC translocation in wild type A20 cells and Fasresistant $\mathbf{A} 20$ cell clones

Upon Fas-stimulation, wild type A20 cells and FasR \#11
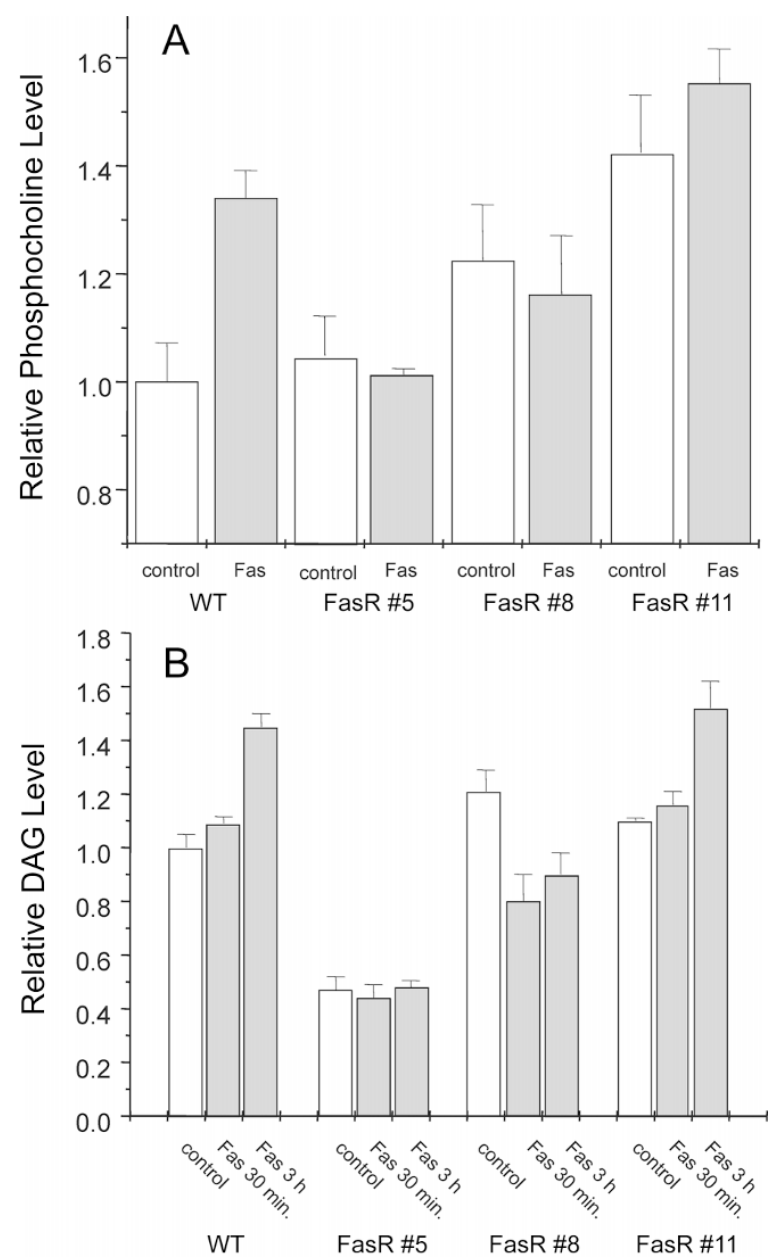

Figure 5. Effects of anti-Fas monoclonal antibody on PC-PLC activity and DAG production in wild type A20 cells and Fas-resistant A20 cell clones. A20 cells $\left(1 \times 10^{6} \mathrm{cell} / \mathrm{s} / \mathrm{ml}\right)$ in 6 -well plates were labeled with $1 \mu \mathrm{Ci} / \mathrm{ml}$ of [methyl- $\left.{ }^{3} \mathrm{H}\right]$ choline chloride $(\mathrm{A})$ or $1 \mu \mathrm{Ci} / \mathrm{ml}$ of $\left[{ }^{3} \mathrm{H}\right]$-palmitic acid $(\mathrm{B})$ in a serum-free medium for $18 \mathrm{~h}$. After labeling, cells were treated with anti-Fas monoclonal antibody for $30 \mathrm{~min}$ or $3 \mathrm{~h}$. Determination of choline phosphate and diacylglycerol level was performed as described in Materials and Method. Results are the mean \pm S.D. from three separate experiments.

clone showed $\mathrm{PKC} \beta \mathrm{I}$ and $\beta I I$ was translocated to membrane fraction from cytosol, while no such translocation was detected in both of FasR \#5 and FasR \#8 clones. In contrast, PMA stimulated PKC translocation in all of the cell lines we tested (Figure 6.).

\section{Effects of anti-Fas monoclonal antibody on SMase activity in wild type A20 cells and Fas-resistant A20 cell clones}

Although Fas-induced hydrolysis of sphingomyelin and subsequent generation of ceramide have been known to be involved in Fas-mediated apoptotic cell death, only wild type and FasR \#11 clone showed the same Fasinduced sphingomyelin hydrolysis pattern (Figure 7). 


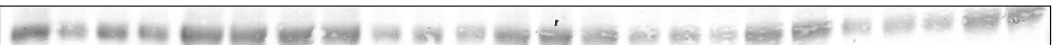

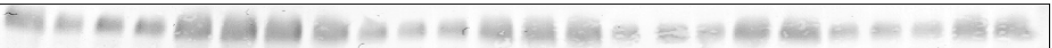

PKC $\beta I$

PKC $\beta I I$

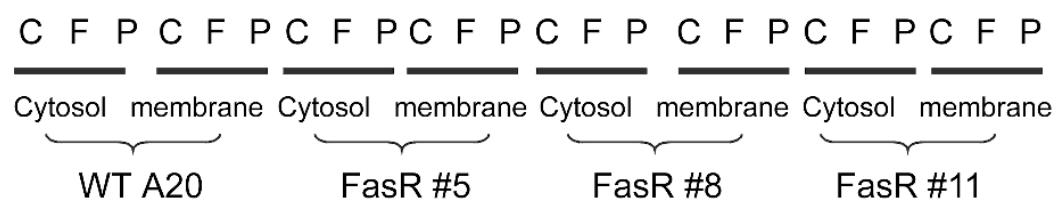

Figure 6. Effects of anti-Fas monoclonal antibody on PKC translocation in wild type A20 cells and Fas-resistant A20 cell clones. A20 cells serum-starved for $18 \mathrm{~h}$ were stimulated with $200 \mathrm{ng} / \mathrm{ml}$ of anti-Fas monoclonal antibody and tested for PKC translocation. Serum-starved cells on 100-mm dishes were stimulated with (F) or without (C) anti-Fas monoclonal antibody for $3 \mathrm{~h}$. As a positive control for PKC translocation to plasma membrane, cells treated with $200 \mathrm{nM}$ PMA (P) for $30 \mathrm{~min}$ were also prepared. The cells were then lysed, subjected to subcellular fractionation into cytosolic fraction and membrane fraction by centrifugation at $100,000 \mathrm{~g}$ and each fraction containing $30 \mu \mathrm{g}$ of protein was analyzed by $10 \%$ SDS-PAGE and subsequent Western blotting using anti-PKC $\beta \mathrm{I}$ and $\beta / \mathrm{I}$ polyclonal antibody.

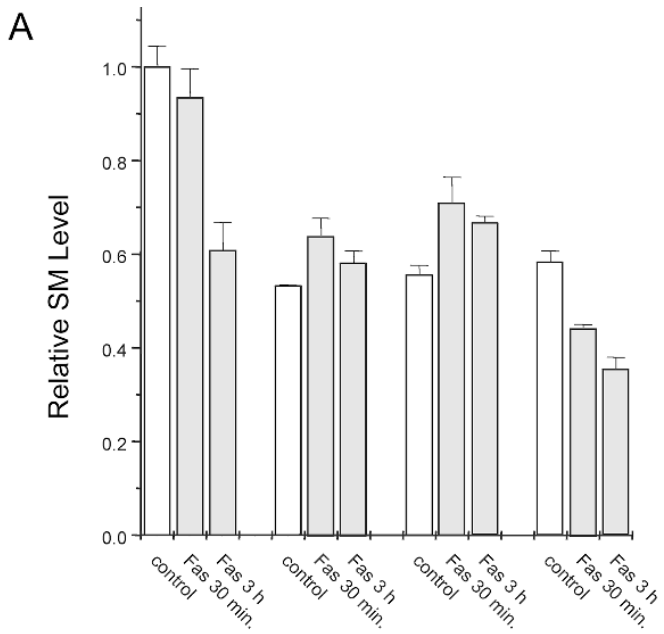

WT FasR \#5 FasR \#8 FasR \#11

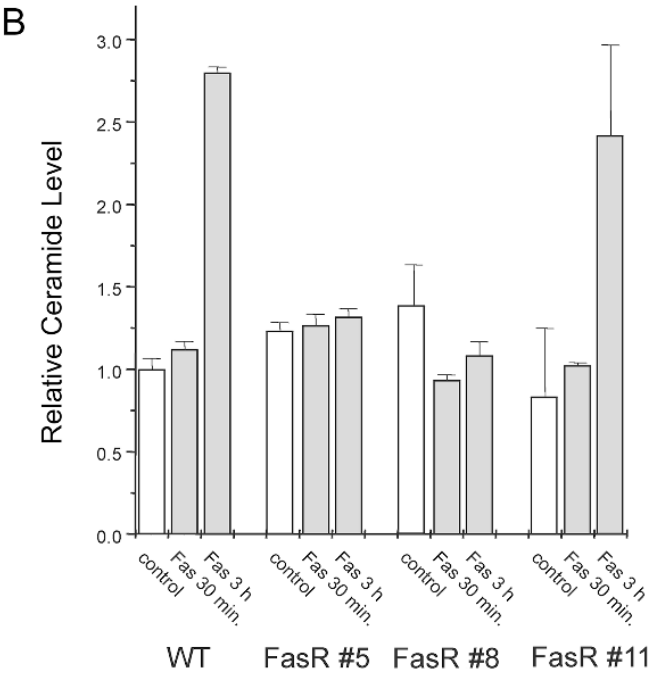

Figure 7. Effects of anti-Fas monoclonal antibody on sphingolipid metabolism in wild type A20 cells and Fas-resistant A20 cell clones. Serumstarved cells on 6 -well plates $\left(1 \times 10^{6} \mathrm{cells} / \mathrm{ml}\right)$ were incubated in serum-free minimum essential medium containing $2 \mu \mathrm{Ci} / \mathrm{ml}$ of $\left[{ }^{3} \mathrm{H}\right]$ serine for $18 \mathrm{~h}$. After the stimulation with anti-Fas monoclonal antibody $(200 \mathrm{ng} / \mathrm{ml})$ for $30 \mathrm{~min}$ or $3 \mathrm{~h}$, the cells were harvested and intracellular levels of sphingomyelin (A) and ceramide $(B)$ were determined according to the methods described in Materials and Methods.
Effect of D609 on anti-Fas monoclonal antibodyinduced protein phosphorylation in wild type A20 cells and Fas-resistant A20 cell clones

As shown in Figure 8, there was a marked increase in protein phosphorylation by anti-Fas monoclonal antibody treatment in wild type A20 and FasR \#11 clone. However, Fas cross-linking showed no effect on protein phosphorylation in the FasR \#5 and \#8 clones. Anti-Fas monoclonal antibody-induced phosphorylation of proteins was inhibited by D609, inhibitor of PC-PLC. These results suggest that Fas stimulates protein phosphorylation and this phosphorylation event is D609sensitive. Although D609 has been known to be a selective inhibitor of PC-PLC, we found that D609 also inhibit protein phosphorylation.

\section{Changes of FLIP expression in Fas-resistant A20 cell clones}

To examine FLIP expression in the wild type A20 cells and Fas-resistant clones, we determined FLIP expression level by Western blot analysis. FLIP expression levels in all

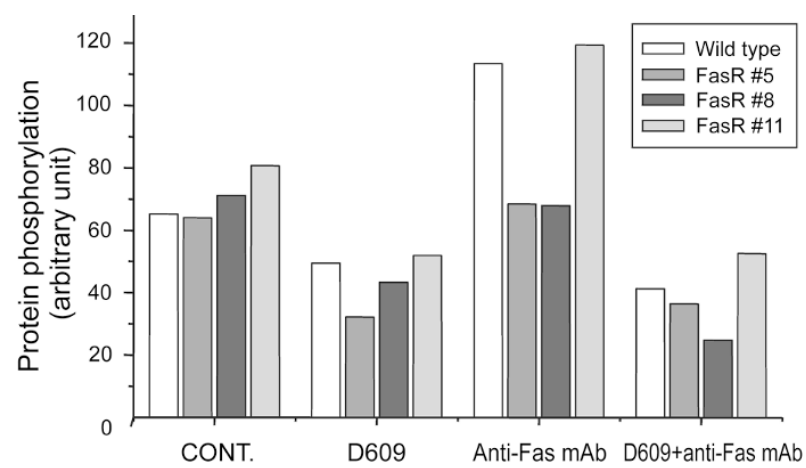

Figure 8. Effects of anti-Fas monoclonal antibody on phosphorylation of protein in wild type A20 cells and Fas-resistant A20 cell clones. A20 cells grown in six-well plates $\left(1 \times 10^{6} \mathrm{cells} / \mathrm{ml}\right)$ were labeled with $100 \mu \mathrm{Ci} / \mathrm{ml}$ of ${ }^{32} \mathrm{P}$ ]orthophosphate for $6 \mathrm{~h}$ in the serum-free medium. After stimulation of the cells with anti-Fas monoclonal antibody for $10 \mathrm{~min}$, the lysates were loaded onto $10 \%$ SDS-PAGE and the cellular phosphoproteins were analyzed subsequent autoradiogram. Quantitation of protein phosphorylation was performed by phosphor image analysis. 


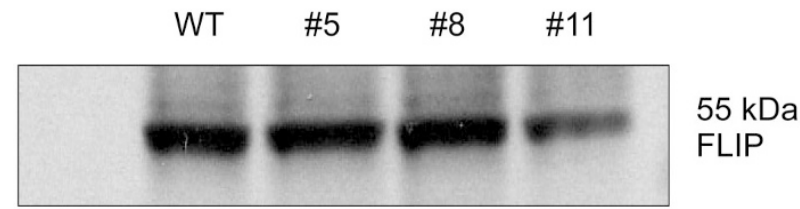

Figure 9. Westren blot analysis of FLIP in wild type A20 cells and Fasresistant A20 cell clones. The cells grown in 100-mm dish were lysed with lysis buffer and disrupted by sonication. Equal protein aliquots of cell lysates $(50 \mu \mathrm{g})$ were loaded onto 15\% SDS-PAGE and Western analysis using the anti-FLIP antisera was performed.

Fas-resistant clones were similar to that of A20 wild type (Figure 9). Therefore, we can rule out the FLIP expression from the candidate that can cause anti-apoptotic tendency found in Fas-resistant clones.

\section{Discussion}

Fas cross-linking in A20 cells results in an increase in PLD activity as determined by a transphosphatidylation reaction (Han et al., 1999). This observation in cells undergoing apoptosis is of particular interest since PLD activity is generally known to be involved in mitogenesis via production of phosphatidic acid (Knauss et al., 1990). Fas is a type I transmembrane protein belonging to the tumor necrosis factor receptor family. Fas triggers an apoptosis-inducing signal when activated through cross-linking with anti-Fas monoclonal antibody or Fas ligand (Kang et al., 1998). In the present study, we generate three different kinds of Fas-resistant A20 cells (FasR \#5, FasR \#8 and FasR \#11). In order to find out what kinds of signal events make this cell be resistant to Fas-induced apoptosis, we checked PLD activity and sphingolipid metabolism after Fas cross-linking with anti-Fas monoclonal antibody, and whether Fasresistant cells encoded alternative spliced Fas, FasB, which has been reported to prevent apoptosis induced by Fas ligand (Hughes and Crispe, 1995). Interestingly, all of three Fas-resistant clones showed increased basal PLD activities. FasR \#5, Fas \#8 and FasR \#11 clones showed 2-folds, 3-4 folds and 2-3 folds increase, respectively, in the basal PLD activity without stimulation. We also demonstrated that expression of PLD2, but not PLD1, was increased in all the Fas-resistant clones compared to that of wild type cells. These data suggest that PLD2 overexpression in Fas-resistant clones contributes to the increased basal PLD activity. PLD1 has low basal activity and is activated by Arf, RalA, RhoA, and PKC $\alpha /$ PKC $\beta$ isoforms in the presence of phosphatidylinositol bisphosphate in vitro (Hammond et al., 1997; Han et al., 1999). PLD2 also essentially requires phosphatidylinositol bisphosphate for its enzyme activity. In contrast to PLD1, it is constitutively active in vitro, and its activity is not affected by PLD1-activating factors such as Arf, RhoA, and PKC in vitro (Colley et al., 1997) but is up-regulated by calcium influx caused by generation of lysophosphatidylcholine with cytosolic phopsholipase A2 (Kim et al., 1999). Recently, Yamakawa et al. (2000) reported that pretreatment of cells with $S$. chromafuscus PLD resulted in inhibition of hypoxia-induced apoptotic cell death and the number of apoptotic cells significantly reduced in PC12 cells overexpressing PLD2. Lee et al. (2000) also reported that PLD2 activity suppressed hydrogen peroxide-induced apoptosis in PC12 cells. These studies raised the possibility that PLD2 activation might play an anti-apoptotic role in cell death as a surviving factor. Our data also showed that all of three Fas-resistant clones overexpressed PLD2 resulting in increased basal PLD activity. Even in wild type A20 cells, Fas-induced cytotoxicity was recovered after treatment of PMA that increased PLD activity through PKC activation. Among Fas-resistant clones we selected, only FasR \#11 clone possessed additional 11$\mathrm{kDa}$ FasB. FasB is generated by incorporation of 158bp between exons 2 and 3 of the reported Fas sequence. This insertion caused a frame shift in exon 3 of the gene, leading early termination. This soluble truncated isoform of Fas retains ligand-binding activity and competes for ligand, thus inhibiting receptor function (Hughes and Crispe, 1995). As we previously reported (Han et al., 1999), Fas cross-linking with antiFas monoclonal antibody in wild type A20 cells increased PC-PLC activity and SMase activity. DAG produced by Fas-induced activation of PC-PLC was responsible for subsequent activation of $P K C \beta I$ and PKC $B I$ and PLD. Ceramide is a product of sphingomyelin breakdown by SMase, and is thought to play a role as a crucial mediator of apoptosis (Hannun and Obeid, 1995). The rapid and transient generation of ceramide by Fas signaling is attributed to acidic SMase (Cifone et al., 1995) and more sustained responses after Fas cross-linking are ascribed to neutral SMase (Boesen-de Cock et al., 1998). There was a marked increase in protein phosphorylation by anti-Fas monoclonal antibody treatment in wild type A20 cells. Although the Fas receptor has no intrinsic kinase activity, recent observations have implicated its roles for both nonreceptor protein tyrosine kinases and protein phosphatases in positive and negative regulation of Fasinduced signaling (Shen and Novak, 1997). FasR \#11 clone showed almost identical results with wild type A20 cells after Fas-cross-linking with anti-Fas monoclonal antibody. In this cell, Fas-resistance might be ascribed to encoding soluble 11-kDa FasB and PLD2 overexpression. In contrast to the wild type A20 and FasR \#11 cells, treatment of anti-Fas monoclonal antibody to both FasR \#5 and FasR \#8 clones showed no elevations in both PC-PLC activity and DAG level. Furthermore, there was no translocation of $\mathrm{PKC} \beta \mathrm{I}$ and $\mathrm{PKC} \beta \mathrm{II}$ from cytosol to membrane fraction upon Fas stimulation. Consequently, 
FasR \#5 clone showed no effect of Fas cross-linking on PLD activity and FasR \#8 clone even showed mild decrease in PLD activity by Fas activation. At present, we do not have any explanation for the decrease in PLD activity by Fas cross-linking in FasR \#8 clone. There should be disconnection in signaling between Fas antigen and PC-PLC in these Fas-resistant clones. Recently, Shin and Han (2000) reported that two different Fas positive cell lines, mouse lymphoma YAC-1 cells and P388D1 mouse lymphoid cells did not show any effect on PC-PLC and PLD activity upon treatment of anti-Fas monoclonal antibody. These cell lines devoid of functional PC-PLC activity could exhibit enhanced PLD activity by exogenous addition of $B$. cereus PC-PLC, suggesting that the activation of PC-PLC is necessary for the activation of PLD by Fas cross-linking (Shin and Han, 2000). PMA treatment stimulated PKC trans-locations and showed meaningful increase in PLD activity in wild type A20 cells and all of three Fas-resistant clones, suggesting that $\mathrm{PKC} /$ PLD pathway is not changed in Fas-resistant clones. There was no effect of Fas cross-linking on sphingomyelin metabolism in both FasR \#5 and FasR \#8 clones. These results raised possibility that these Fas-resistant clones' character might be conferred by defect in ceramide generating machinery. Taken together, in FasR \#5 and FasR \#8 clones, Fas-resistance might be ascribed to PLD2 overexpression and defect in ceramide generating machinery like SMase.

\section{Acknowledgements}

This work was supported by a grant (2001) from Hanyang University and partly by a grant R01-200000132 from the Basic Research Program of the Korea Science and Engineering Foundation and through the Research Center for Bio-Medicinal Resources, Pai Chai University.

\section{References}

Alderson MR, Armitage RJ, Maraskovsky E, Tough TW, Roux E, Schooley K, Ramsdell F, Lynch DH. CD40 expression by human monocytes: regulation by cytokines and activation of monocytes by the ligand for CD40. J Exp Med 1993;178: 2231-35

Bligh KM, Dyer WJ. A rapid method of total lipid extraction. Can J Biochem Physiol 1959;37:911-17

Boesen-de Cock JGR, Tepper AD, de Vries E, van Bliterswijk WJ, Borst J. CD95 (Fas/APO-1) induces ceramide formation and apoptosis in the absence of a functional acid sphingomyelinase. J Biol Chem 1998;273:7560-65

Cifone MG, Roncaioli P, de Maria R, Carmada G, Santoni A, Ruberti G, Testi R. Multiple pathways originate at the Fas/ APO-1 (CD95) receptor: sequential involvement of phosphatidylcholine-specific phospholipase $\mathrm{C}$ and acidic sphingomyelinase in the propagation of the apoptotic signal. EMBO J 1995;14:5859-68

Cook SJ, Walkenlan MJO. Analysis of the water-soluble products of phosphatidylcholine breakdown by ion-exchange chromatography. Bombesin and TPA (12-O-tetradecanoylphorbol 13-acetate) stimulate choline generation in Swiss 3T3 cells by a common mechanism. Biochem J 1989;263:581-87

Dhein J, Walczak H, Baumler C, Debatin KM, Krammer PH. Autocrine T-cell suicide mediated by APO-1/(Fas/CD95). Nature 1995;373:438-41

Djerbi M, Screpanti V, Catrina Al, Bogen B, Biberfeld P, Grandien A. The inhibitor of death receptor signaling, FLICEinhibitory protein defines a new class of tumor progression factors. J Exp Med 1999;190(7):1025-31

Goillot E, Raingeaud J, Ranger A, Tepper RI, Davis RJ, Harlow E, Sanchez I. Mitogen-activated protein kinasemediated Fas apoptotic signaling pathway. Proc Natl Acad Sci USA. $1997 ; 94: 3302-7$

Gomez-Munoz A, Martin A, OBrien L, Brindley DN. Cellpermeable ceramides inhibit the stimulation of DNA synthesis and phospholipase D activity by phosphatidate and lysophosphatidate in rat fibroblasts. J Biol Chem 1994;269: 8937-43

Ha KS, Exton JH. Differential translocation of protein kinase C isozymes by thrombin and platelet-derived growth factor. A possible function for phosphatidylcholine-derived diacylglycerol. J Biol Chem 1993;268:10534-39

Hammond SM, Jenco JM, Nakashima S, Cadwallader K, Gu Q, Cook S, Nozawa Y, Prestwich GD, Frohman MA, Morris AJ. Characterization of two alternately spliced forms of phospholipase D1. Activation of the purified enzymes by phosphatidylinositol 4,5-bisphosphate, ADP-ribosylation factor, and Rho family monomeric GTP-binding proteins and protein kinase C-alpha. J Biol Chem 1997;272:3860-68

Han J-S, Hyun BC, Kim JH, Shin I. Fas-mediated activation of phospholipase $D$ is coupled to the stimulation of phosphatidylcholine-specific phospholipase C in A20 cells. Arch Biochem Biophys 1999;367:233-39

Han J-S, Shin I. Ceramide does not inhibit protein kinase Câdependent phospholipase D activity stimulated by anti-Fas monoclonal antibody in A20 cells. Cell Signal 2000;12:731-36

Hannun YA, Obeid LM. Ceramide: an intracellular signal for apoptosis. TIBS 1995;20:73-77

Heller RA, Krönke M. Tumor necrosis factor receptormediated signaling pathways. J Cell Biol 1994;126:5-9

Hughes DP, Crispe IN. A naturally occurring soluble isoform of murine Fas generated by alternative splicing. J Exp Med 1995;182:395-401

Irmler M, Thome M, Hahne M, Schnelder P, Hofmann K, Steiner V, Bodmer JL, Schröter M, Burns K, Mattmann C, Rimoldi D, French LE, Tschopp J. Inhibition of death receptor signals by cellular FLIP. Nature 1997;388:190-95

Itoh N, Yonehara S, Ishii A, Yonehara M, Mizushima S-I, 
Sameshima M, Hase A, Seto Y, Nagata S. The polypeptide encoded by the cDNA for human cell surface antigen Fas can mediate apoptosis. Cell 1991;66:233-43

Kagi D, Vignaux F, Ledermann B, Burki K, Depraetere V, Nagata S, Hengartner H, Goldstein P. Fas and perforin pathways as major mechanisms of T cell-mediated cytotoxicity. Science 1994;265:528-30

Kang JH, Shin I, Han J-S. Changes of phospholipase D activity in TNF-alpha and anti-Fas/Apo1 monoclonal antibody induced apoptosis in HL-60 and A20 cells. Exp Mol Med 1998;30:21-27

Kim JH, Lee BD, Kim Y, Lee SD, Suh P-G, Ryu SH. Cytosolic phospholipase A2-mediated regulation phospholipase D2 in leukocyte cell lines. J Immunol 1999;163:5462-70

Knauss TC, Jaffer FE, Abboud HE. Phosphatidic acid modulates DNA synthesis, phospholipase C, and plateletderived growth factor mRNAs in cultured mesangial cells : role of protein kinase C. J Biol Chem 1990;265:14457-63

Lee M-Y, Jo Y-H, Chun M-H, Chung J-W, Kim M-S, Min DS. Immunohistochemical localization of phospholipase D1 in rat central nervous system. Brain Res 2000;864,52-59

Lee SD, Lee BD, Han JM, Kim JH, Kim Y, Suh P-g, Ryu SH. Phospholipase D2 activity suppresses hydrogen peroxideinduced apoptosis in PC12 cells. J Neurochem 2000;75:1053-59

Meacci E, Vasta V, Neri S, Farnararo M, Bruni P. Bradykinin stimulates fructose 2,6-bisphosphate metabolism in human fibroblasts. Biochem Biophys Res Commun 1996;225:392-99

Mosmann T. Methods. Rapid colorimetric assay for cellular growth and survival: application to proliferation and cytotoxicity assays. J Immunol Methods 1983;65:55-63

Nagata S, Goldstein P. The Fas death factor. Science 1995;267: 1449-56

Park BJ, Kim JH, Han J-S, Jung PM. Effect of ceramide on apoptosis and phsopholipase D activity in FRTL-5 thyroid cells. Exp Mol Med 1999;31(3):142-50

Santana P, Llanes L, Hernandez I, Gallardo G, Quintana J, Gonzalez J, Estevez F, Ruiz de Galarreta C, Fanjul LF. Ceramide mediates tumor necrosis factor effects on P450aromatase activity in cultured granulosa cells. Endocrinology 1995; 136:2345-48

Shen K, Novak RF. Fas-signaling and effects on receptor tyrosine kinase signal transduction in human breast epithelial cells. Biochem Biophys Res Commun 1997;230:89-93

Shin I, Han J-S. Phosphatidylcholine-specific phospholipase C-mediated induction of phospholipase D activity in Fasexpressing murine cells. Comp Biochem Physiol Part B 2000;126:445-53

Watanabe-Fukunaga R, Brannan C I, Itoh N, Yonehara S, Jenkins NA, Nagata $S$. The cDNA structure, expression, and chromosomal assignment of the mouse Fas antigen. J Immunol 1992;148:1274-79

Yamakawa H, Banno Y, Nakashima S, Sawada M, Yamada J, Yoshimura S, Nishimura Y, Nozawa Y, Sakai N. Increased phospholipase D2 activity during hypoxia-induced death of PC12 cells: its possible anti-apoptotic role. Neuroreport 2000;11:3647-50 